\title{
Preoperative Assessment Using Multimodal Functional Magnetic Resonance Imaging Techniques in Patients with Brain Gliomas
}

\author{
Beyin Gliomlu Hastalarda Multimodal Isslevsel Manyetik Rezonans \\ Görüntüleme Teknikleri Kullanılarak Preoperatif Değerlendirme
}

Han-bing SHANG, Wei-guo ZHAO, Wei-feng ZHANG

Rui Jin Hospital, Shanghai Jiao Tong University, Faculty of Medicine, Department of Neurosurgery, Shanghai, China

Correspondence address: Wei-guo ZHAO / E-mail: rjneurosurgery@gmail.com

\begin{abstract}
AIM: To evaluate the value of magnetic resonance spectroscopy (MRS), blood oxygen level-dependent imaging (BOLD) and diffusion tensor imaging (DTI) for preoperative assessment in patients with brain gliomas.

MATERIAL and METHODS: Twenty-three consecutive glioma patients underwent MRS, BOLD and DTI before operation. The characteristics of images were analysed according to histopathological results.

RESULTS: There is significant elevation of the choline (Cho) /creatine $(\mathrm{Cr})$ ratio, Cho peak and depression of the N-acetylaspartate (NAA) peak in gliomas. Elevation of the $\mathrm{Cho} / \mathrm{Cr}$, Cho/NAA ratio and the presence of a lipids peak, were consistent with high-grade malignancy. A motor activation scan was achieved by using a motor task paradigm in 20 patients. Deformation and displacement of the motor activations was found in 5 cases. The margin of tumor and peritumoural white matter tracts were identified using apparent diffusion coefficient (ADC) and fractional anisotropy (FA) maps. Three patterns of white matter tracts alteration were identified: displacement, infiltration, and disruption. In all 23 patients, the tumors were completely resected in 6 patients, subtotal resected in 8 patients, partial resected in 9 patients. No secondary neurological deficit was occurred in all patients after operation.
\end{abstract}

CONCLUSION: The combination of MRS, BOLD, and DTI techniques allows appropriate presurgical planning of brain gliomas.

KEYWORDS: Glioma, Operation, Functional magnetic resonance imaging

öz

AMAÇ: Beyin gliomlu hastalarda preoperatif değerlendirme için manyetik rezonans spektroskopisi (MRS), kan oksijen seviyesine bağımlı görüntüleme (BOLD) ve difüzyon tensor görüntülemenin (DTI) önemini değerlendirmek.

YÖNTEM ve GEREÇLER: Arka arkaya 23 gliom hastasında ameliyat öncesinde MRS, BOLD ve DTI yapıldı. Görüntülerin özellikleri histopatolojik sonuçlara göre değerlendirildi.

BULGULAR: Gliomlarda kolin (Cho) /kreatin (Cr) oranı ve Cho tepe değerinde önemli artış varken N-asetilaspartat (NAA) tepe değerinde azalma görülür. Cho/Cr ve Cho/NAA oranı artışı ve bir lipid tepe değerinin varlığı yüksek dereceli malignansi ile tutarlıydı. Bir motor görev paradigması kullanılarak 20 hastada bir motor aktivasyon taraması yapıldı. Beş vakada motor aktivasyonlarda deformasyon ve displasman bulundu. Peritümöral beyaz madde kanalları ve tümör kenarı görünür difüzyon katsayısı (ADC) ve fraksiyonel anisotropi (FA) haritaları kullanılarak tanımlandı. Üç beyaz madde kanalı değişme paterni tanımlandı: displasman, infiltrasyon ve bozulma. Bu 23 hasta içinde 6 hastada tamamen tümör rezeksiyonu yapıldı, 8 hastada subtotal rezeksiyon yapıldı ve 9 hastada kısmi rezeksiyon yapıldı. Ameliyattan sonra hiçbir hastada ikincil nörolojik defisit görülmedi.

SONUÇ: MRS, BOLD ve DTI tekniklerinin kombinasyonu beyin gliomlarında cerrahi öncesi uygun planlamayı mümkün kılar.

ANAHTAR SÖZCÜKLER: Gliom, Operasyon, İşlevsel manyetik rezonans görüntüleme

\section{INTRODUCTION}

Nowadays, with the development of modern radiological technology, more and more advanced imaging techniques used in preoperative evaluation of patients with cerebral neoplasms. These include computed tomography (CT) and magnetic resonance (MR) angiography and venography, $C T$ and MR perfusion, MR spectroscopy (MRS), blood oxygen level-dependent imaging (BOLD), and diffusion tensor imaging (DTI) (21). Among these methods, MRS, BOLD, and DTI can add important functional aspects to conventional anatomical brain imaging, which has become available for the clinical evaluation of various brain lesions (35). In this study, the role of these functional imaging techniques in preoperative evaluation for brain glioma were analysed. 


\section{MATERIAL and METHODS}

A total of 23 patients with gliomas received surgical treatment at Ruijin hospital of Shanghai Jiaotong University School of Medicine. All patients were performed proton MRS, BOLD, and DTI scan before surgery, the results of preoperative imaging were evaluated for determination of surgical strategy, and compared with histopathological results and clinical outcomes. Among these patients, 14 were male and 9 were female, age from 11 73 years (mean age, $46 \mathrm{yr}$ ). Initial symptoms of the 23 patients included headache, vomiting, seizure, limb numbness, or weakness. The Karnofsky Performance Scales (KPS) of the patients was 60 in 1 case, 70 80 in 5 cases, 80 100 in 17 cases.

Preoperative radiological evaluation as follow: (1) proton MRS: A large region of interest (ROI), which included the tumor as well as either contralateral or remote ipsilateral normalappearing brain tissue, was defined for detection of the compound of interest. These five resonances included choline (Cho) at $3.2 \mathrm{ppm}$, creatine (Cr) at $3.0 \mathrm{ppm}, \mathrm{N}$-acetyl aspartate (NAA) at 2.0ppm, lactate (Lac) at $1.3 \mathrm{ppm}$, and lipid (Lip) at $0.9 \mathrm{ppm}$. (2)BOLD: The primary motor cortex was mapped using BOLD imaging, then the shape and position of motor activations were observed, and the anatomic relationship between the tumor borders and functionally eloquent cortex was measured. (3)DTI: Apparent diffusion coefficients (ADC) and fractional anisotropy (FA) were measured in regions of enhancing tumor, hyperintense regions adjacent to enhancing tumor, normal-appearing tissures in the contralateral areas. The major white matter tracts were represented using diffusion tensor tractography technique. The integrity of white matter tracts in the surrounding border zone of the tumors was investigated before surgery.

According the preoperative radiological results, operative plan including surgical approach and resection extent of tumors were made before operation. All patients underwent conventional MRI scan two weeks to one month after tumor resection. MRS, BOLD and DTI data were compared to the pathological results.

\section{RESULTS}

\section{Location and histological types of the tumors}

In all 23 tumors, 9 tumors were located in frontal lobe, 8 in temporal lobe, 2 in frontal-temporal, 3 in parietal lobe, and 1 in corpus callosum. After operation, pathological results showed astrocytoma tumor in 13 cases, oligodendroglioma in 4 cases, glioblastoma in 6 cases. All patients were classified into two groups, 9 cases were in low-grade (WHO I II grade) and 14 cases in high-grade group (WHO III IV grade).

\section{The characteristics of proton MRS}

Compared with normal brain tissue, different changes of lowmolecular weight chemicals were found in both high-grade and low-grade gliomas. Decrease or absence of NAA, and elevation of Cho were the general markers for brain gliomas. There was significant elevation of the $\mathrm{Cho} / \mathrm{Cr}$ ratio and Cho/
NAA ratio, and depression of the NAA/Cr ratio in gliomas. Elevation of the $\mathrm{Cho} / \mathrm{Cr}$, Cho/NAA ratio and the presence of a lipids peak, consistent with high-grade malignancy (Figure $1 \mathrm{~A}-\mathrm{F})$.

The levels of metabolic element of proton MRS between the low-grade group and high-grade group were analysed, Cho/ $\mathrm{Cr}$, Cho/NAA, and LL/Cr were significantly higher in highgrade gliomas (Table I).

\section{The characteristics of BOLD}

In 20 patients of all cases, a motor activation scan was successfully achieved using a motor task paradigm. The motor activation presented three different patterns due to the location, size and mass effect of the tumor. These three categories of activation included disparative activation plaque, deformation and displacement of the motor activations, and normal activation clusters. In the present study, motor activations remained normal in 8 patients, were deformed and displaced by tumor in 5 patients. Among these 5 patients, moter activation clusters were compressed and displaced to occipital in 2 cases, to lateral in 2 cases, to frontal in 1 case (Figure 2).

\section{The characteristics of DTI}

In all 23 patients, the tumor border and peritumoral infiltration were delineated clearly on color-coded ADC and FA maps (Figure 3A-F). Meanwhile, fiber tracts around the tumor were reconstructed using diffusion tensor tractography (DTT). Three patterns of white matter tracts alteration were identified: displacement, infiltration, and disruption. In this study, we found that more than one of these three typical radiological manifestation usually co-existent. As for these 23 patients, infiltration and disruption were found in 5 patients, displacement and disruption in 4 patients, displacement and infiltration in 11 patients, and displacement in 3 patients.

\section{The preoperative radiological evaluation and the surgical outcome}

Types and grades of tumor, the distance between tumor periphery and eloquent area, and the relationship between tumor and white matter tracts were evaluated before operation. According to these preoperative functional MRI results, we were able to predict the resection extent of tumor, postoperative loss of neurological function and to design the surgical procedure. All patients received enhanced MRI scan in two week to one month after operation, radical resection was attempted in 6 cases, subtotal resection in 8 cases, and partial resection in 9 cases. All patients experienced no added permanent postoperative sequelae. Except for one patient whose preoperative KPS was 60 , the other patients achieved above KPS 90 during follow-up period.

\section{DISCUSSION}

\section{The value of preoperative proton MRS in surgical treatment of brain glioma}

The clinical application of MRS is slowly becoming a routine part of the initial diagnostic exam for brain mass. As a 

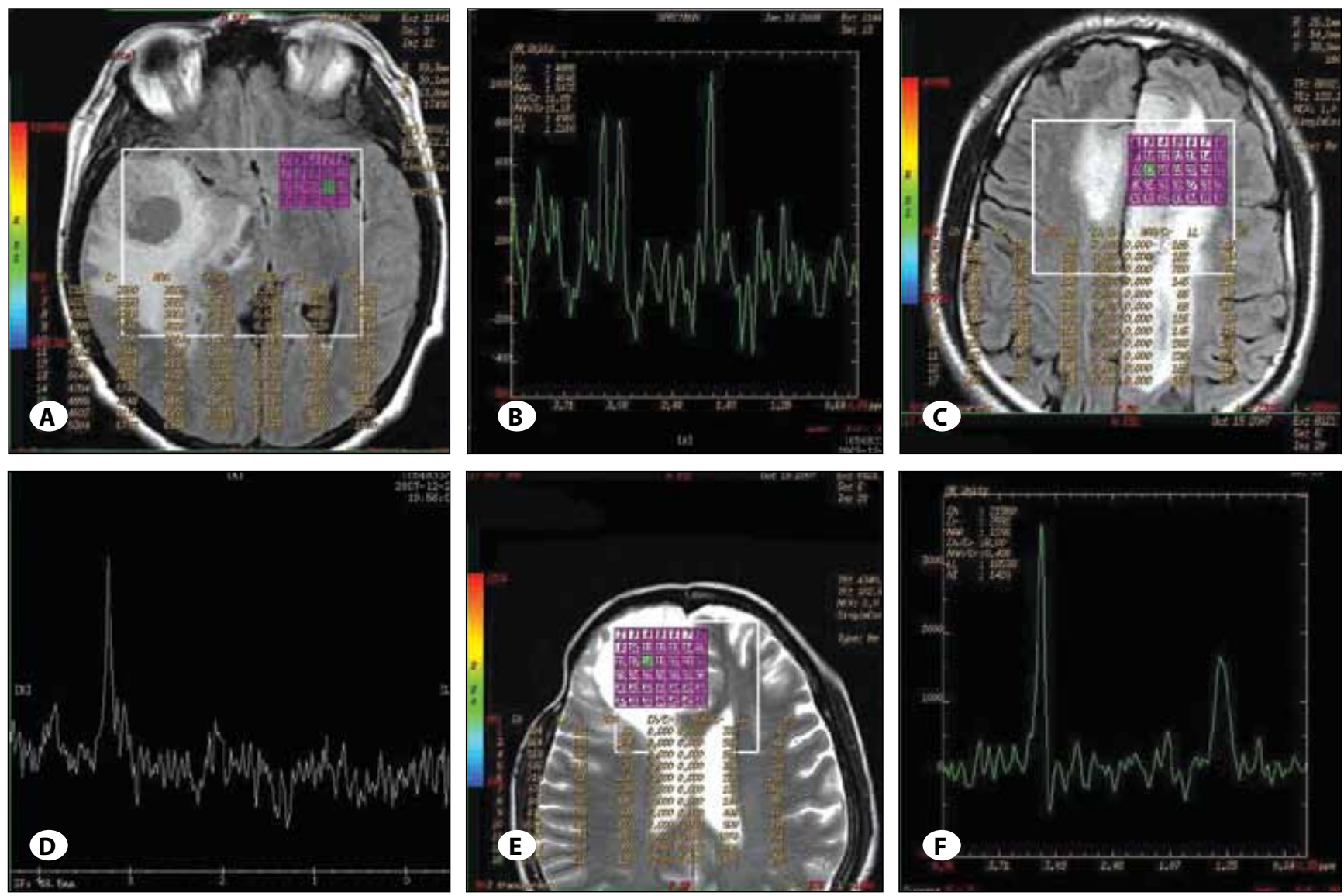

Figure 1: Proton magnetic resonance spectroscopy scan focusing on volume elements of normal brain tissue (A), WHO 1 grade glioma (C), and WHO 4 grade glioma (E), with corresponding spectrum on right side. The spectrum of normal brain tissue (B) shows signal patterns for various metabolites as follows: $\mathrm{N}$-acetylaspartate (NAA) at $2.05 \mathrm{ppm}$; Creatine (Cr) at 3.03ppm; Choline (Cho) at 3.22ppm. The spectrum of low-grade glioma (D) shows an increased level of Cho and a decreased level of NAA, which presents the typical tumor pattern. The spectrum of high-grade (F) shows a high level of Cho, undetectability of Cr and NAA, and high lactate/lipids (LL) peak which suggests the presence of necrosis.

Table I: Comparison of Metabolic Elements Levels Between Low-Grade and High-Grade Glioma

\begin{tabular}{|l|c|c|c|c|c|c|}
\hline & Cho & NAA & Cr & Cho/Cr & Cho/NAA & LL/Cr \\
\hline $\begin{array}{l}\text { Low-grade group } \\
\text { ( cases) }\end{array}$ & $332.33 \pm 57.11$ & $143.50 \pm 43.56$ & $226.17 \pm 62.74$ & $1.63 \pm 0.72^{*}$ & $2.65 \pm 1.377^{\mathbf{\Delta}}$ & $0.62 \pm 0.43^{\boldsymbol{\nabla}}$ \\
$\begin{array}{l}\text { Low-grade group } \\
\text { (14 cases) }\end{array}$ & $1256.50 \pm 280.94$ & $99.83 \pm 27.87$ & $335.67 \pm 96.79$ & $3.91 \pm 1.01$ & $13.46 \pm 4.45$ & $4.54 \pm 1.71$
\end{tabular}

$\boldsymbol{P}^{*}=0.001, \boldsymbol{P}^{\mathbf{4}}=0.001, \boldsymbol{P}^{\mathbf{v}}=0.002$ 。

Cho: cholines, NAA: N-acetylaspartate, Cr: creatine, LL: lactate/lipids.

noninvasive method of classifying brain lesions, the MRS can provide information on the biochemical profile of tumor, peritumoral edema and normal brain tissue $(23,36)$. In our experiences, the MRS data can provide unique information that when combined with BOLD and DTI has implications for defining tumor type and grade, directing biopsy or surgical resection. To review the findings of this study and relative literatures $(1,3,4,6-8,15-18,19,28,31,38)$, typical changes of various metabolites among different types of lesions were summarized in Table II.
The value of proton MRS for predicting tumor malignancy which was known as an important branch of clinical application has been reported in several prior clinical studies $(5,12-14,19,22,27)$. Similar to our results, the ratio of $\mathrm{Cho} / \mathrm{Cr}$ and Cho/NAA in high grade gliomas were found significantly higher than in low grade gliomas, and lipid peak was usually defined in high grade gliomas, which was strongly associated with the presence and amount of necrosis in glioma. Therefore, the $\mathrm{Cho} / \mathrm{Cr}$, Cho/NAA ratios and lipid signal may be useful clinical radiological markers for predicting pathological 


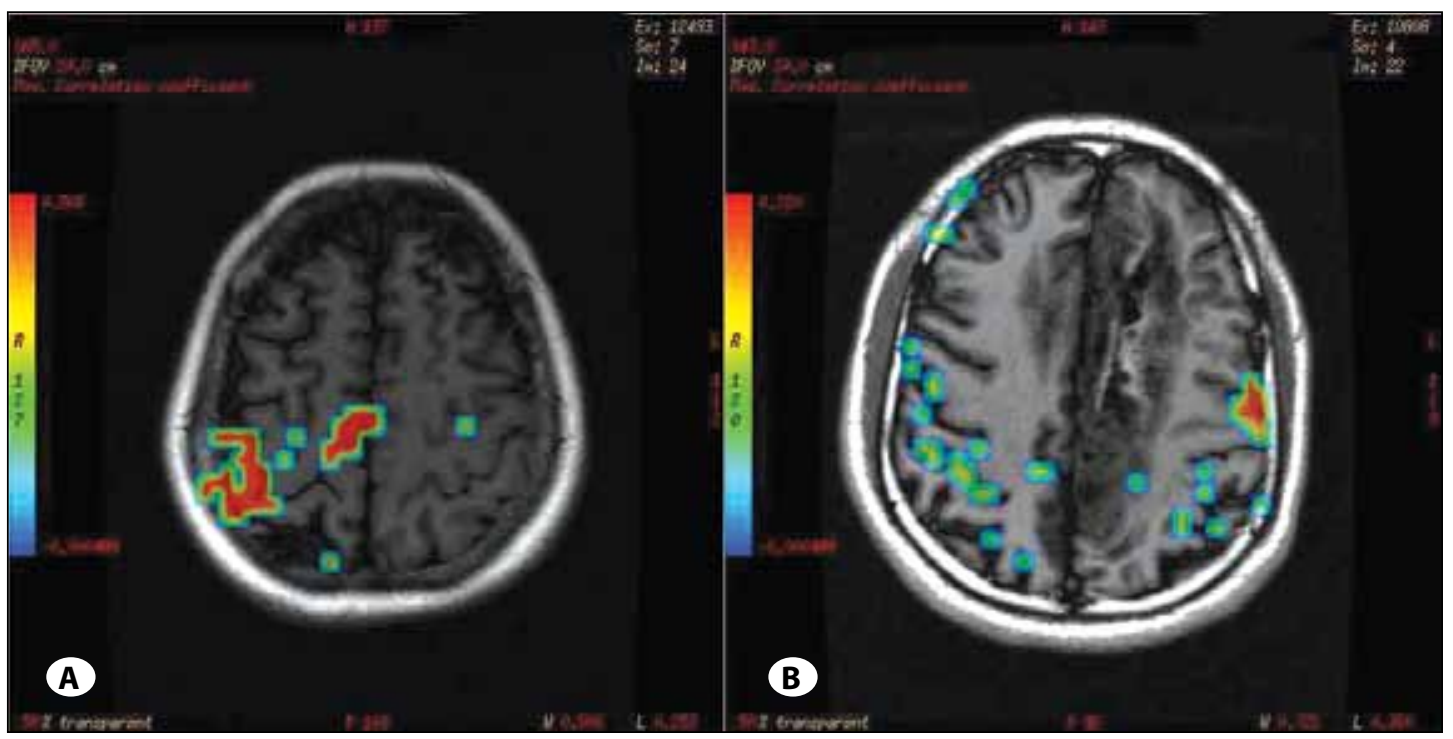

Figure 2: BOLD

images show the normal motor areas (left) and the distorted motor activation which was obviously compressed to lateral to the tumor.

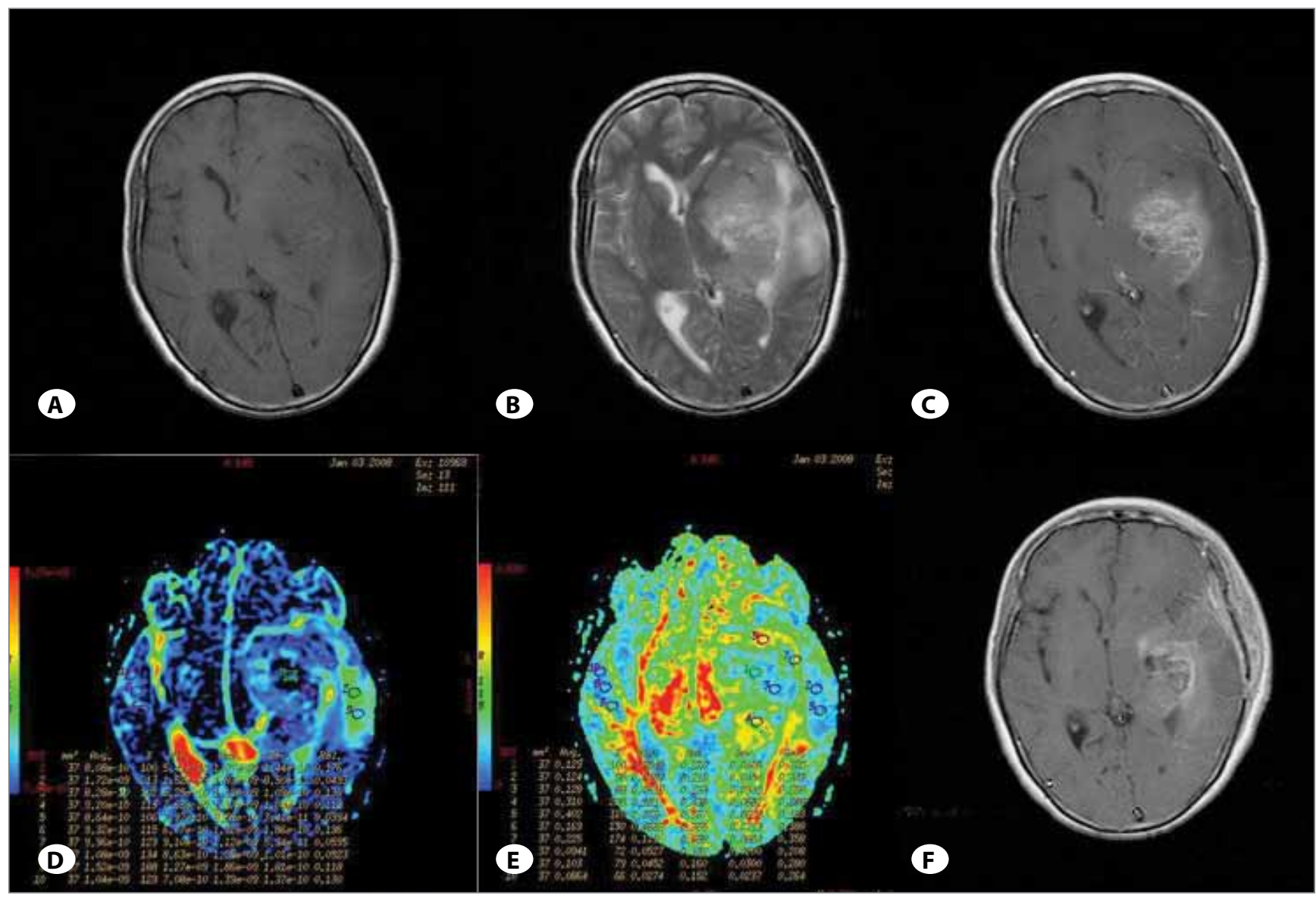

Figure 3: Conventional MRI show no obvious tumor margin on both T1 and T2 weighted images (A,B), and axial contrast-enhanced T1 weighted MR image shows partial enhancing lesion with peritumoral infiltration in the left temporal lobe (C). On color-coded ADC map, the tumor border and peritumor edema can be distinguished clearly (D). The color-coded FA map shows disruption and displacement of the white matter tracts around the tumor (E). Postoperative MRI demonstrates that the tumor was subtotal resected (F), with no added loss of neurological function. 
Table II: Proton MRS Characteristics of Different Intracranial Lesions

\begin{tabular}{|c|c|c|c|c|c|c|c|c|c|}
\hline & Cho & $\mathrm{Cr}$ & NAA & $\mathrm{Cho} / \mathrm{Cr}$ & $\mathrm{NAA} / \mathrm{Cr}$ & Lac & Lip & Ala & MI \\
\hline Glioma & $\uparrow$ & $\uparrow \downarrow$ & $\downarrow$ & $\uparrow$ & $\downarrow$ & $\uparrow$ & $\uparrow$ & - & - \\
\hline Meningioma & $\uparrow$ & $\uparrow \downarrow$ & - & $\uparrow$ & - & - & - & $\uparrow$ & - \\
\hline Hemangiopericytoma & $\uparrow$ & $\uparrow \downarrow$ & - & $\uparrow$ & - & - & - & - & $\uparrow$ \\
\hline Metastatic tumor & $\uparrow$ & $\uparrow \downarrow$ & - & $\uparrow$ & - & - & - & - & - \\
\hline Gliosis & $\uparrow$ & $\uparrow \downarrow$ & $\downarrow$ & - & - & - & - & - & $\uparrow$ \\
\hline Acute cerebral infarction & $\downarrow$ & $\uparrow \downarrow$ & $\downarrow$ & - & - & $\uparrow$ & - & - & - \\
\hline Acute encephalitis & - & - & $\downarrow$ & - & $\downarrow$ & - & - & - & - \\
\hline Radiation necrosis & $\downarrow$ & $\downarrow$ & $-\downarrow$ & $\downarrow$ & - & $\uparrow \downarrow$ & $\uparrow \downarrow$ & $-\downarrow$ & $-\downarrow$ \\
\hline Brain abscess & $\downarrow$ & $\downarrow$ & $\downarrow$ & $\downarrow$ & $\downarrow$ & $\uparrow$ & $\uparrow$ & $\uparrow$ & - \\
\hline
\end{tabular}

Ala: alanine, MI: myo-inositol.

grades of gliomas. However, some studies have found highgrade tumors to have lower levels of Cho than low-grade tumors (e.g. grade 2 or grade 3 astrocytoma) (11). This may be due to the presence of necrosis in high grade tumors, since necrosis is associated with low levels of all metabolites. Hence, the ROI chosen for analysis will have a large influence on the results, and the maximum Cho signal in multi-voxel MRS images is considered preferable to be chosen for analysis (34).

In brief, because of lesion variability, heterogeneity, overlap between different tumor types, and also dependence of data collection and analysis techniques, these results have proven difficult to replicate in general clinical practice. Therefore, it is very difficult for a clinician to use MRS alone to diagnose a brain lesion with high confidence. Rather, MRS should perhaps be seen as an adjunct technique that may contribute to differential diagnoses that are being considered on the basis of MRI, clinical and other information.

\section{The value of preoperative BOLD in surgical treatment of brain glioma}

For gliomas involving sensorimotor cortices, the main goal of surgery is to balance maximal tumor resection and preservation of the eloquent areas. Although radiological techniques such as CT scanning and MR imaging can define the intracranial location of the tumor, they generally do not provide information about the functional viability of adjacent radiologically normal tissue. Whereas assumptions about the anatomic loci of functional organization may be made based on historical experience, such assumptions may not apply in individual patients in whom, for example, mass lesions may have led to anatomic displacement, or when, over the period of growth of the lesion, cortical reorganization of functional areas may have occurred $(26,32)$. The need for definition of eloquent cortex in the individual patient led to the clinical application of BOLD imaging, which is a noninvasive method increasingly used for the presurgical evaluation. Benson et al. (2) compared the laterality of language dominance determined by BOLD with those determined by Wada testing or electrocortical stimulation mapping in 23 patients, 22 of them was concordant with invasive measures. Roberts et al. (29) compared preoperative BOLD mapping to intraoperative cortical stimulation mapping, and found that magnetic source imaging results were reasonably concordant with intraoperative mapping findings in over $90 \%$ of cases. Haberg et al. (10) evaluate the usefulness of BOLD in presurgical planning, and to assess the functional outcome in 25 patients with primary brain tumors involving the eloquent areas. They concluded that a distance of $10 \mathrm{~mm}$ or more between the functional cortex and the tumor significantly reduced the risk of postoperative loss of function, and the information obtained by BOLD was useful in the preoperative planning. In the present study, preoperative brain mapping with BOLD individually showed the anatomical relationship of somatosensory areas to tumour in vivo, optimized operative plan and guided surgical approach in 5 patients, although we were unable to integrate these functional images into surgical navigation system which had been described in recent literatures $(9,30,33)$.

In conclusion, presurgical BOLD imaging in patients with brain glioma is a promising clinical application with added value. However, BOLD imaging has not yet reached the widespread clinical acceptance. This is due to numberous disadvantages and technical problems, such as lack of correct spatial localization, gross head movement, ghosting, limited success rate, and the lack of information about the underlying white matter structures and connections (35). Therefore, combining presurgical BOLD images with other techniques such as DTI and neuro-navigation will be a clinical trend in the near future.

\section{The value of preoperative DTI in surgical treatment of brain glioma}

Although BOLD functional MRI can locate eloquent areas reliably, they cannot provide precise information about the position and integrity of subcortical fiber bundles, which may be important in avoiding neurological deficit after operation. In recent years, the technique of diffusion-weighted imaging 


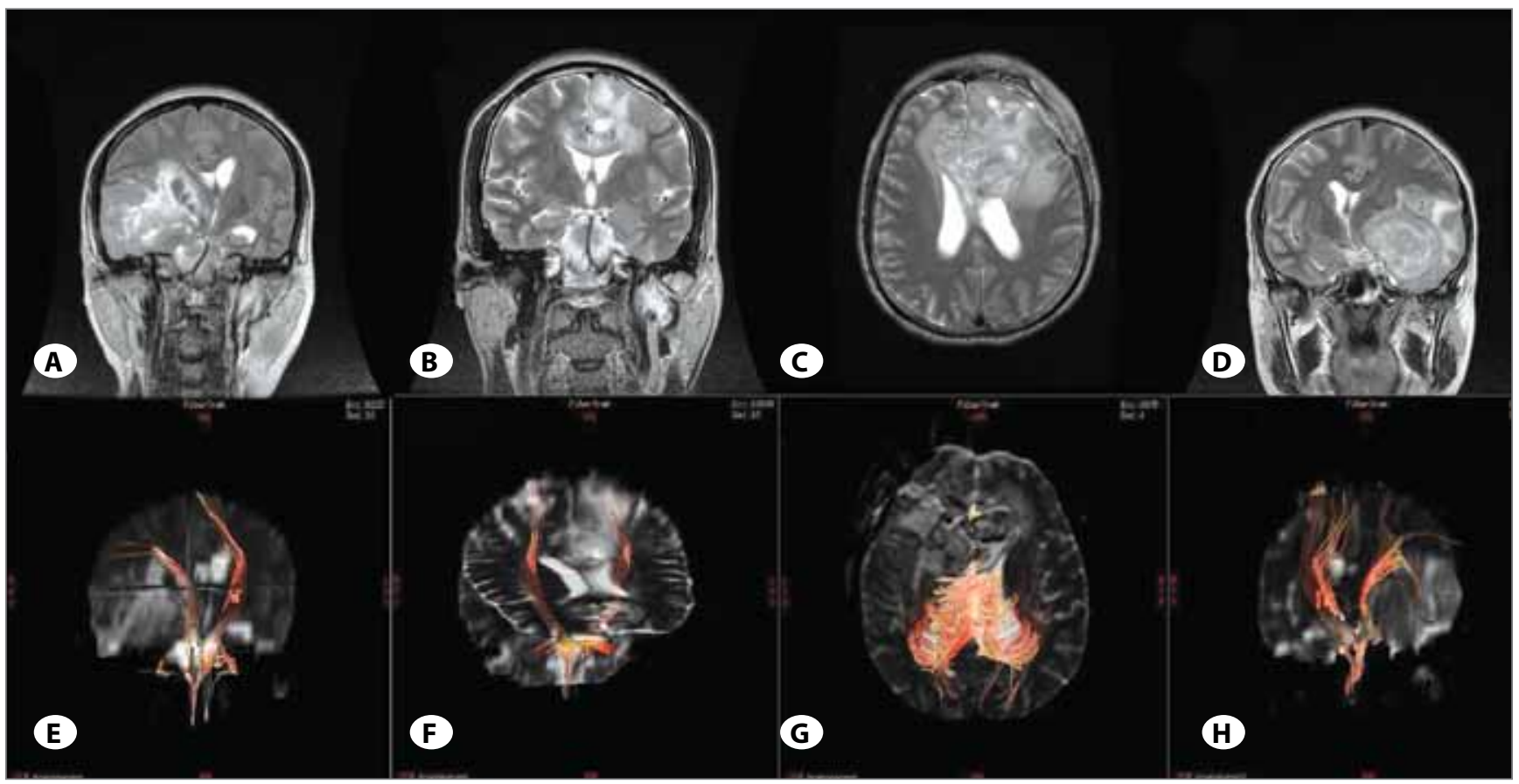

Figure 4: The types of white matter tracts alteration were demonstrated as follows: 1 Displacement: a coronal T2 weighted MR image shows a right temporal glioma with significant mass effect, and the midline was compressed to contralateral (A), three-dimensional reconstruction of bilateral pyramidal tracts depicts that the right pyramidal tracts were compressed to left side, but maintained complete fiber structure (E); 2 Displacement and infiltration: a coronal T2 weighted MR image shows a left parietal glioma with peritumoral edema (B), the left pyramidal tracts were located in the region of peritumoral edema, and showed sparse and displaced on three-dimensional reconstruction map (F); 3 Infiltration and disruption: a axial T2 weighted MR image shows a large, mixed signals lesion locating in the anterior corpus callosum (C), fiber tracking shows that the fiber tracts were interrupted and infiltrated by tumor (G); 4 Displacement and disruption: a coronal T2 weighted MR image shows a left temporal glioma with significant mass effect (D), three-dimensional reconstruction of bilateral pyramidal tracts depicts that the left pyramidal tracts were disrupted and compressed to right side (H).

has been increasingly applied in clinical routine, especially in fiber tracking, which provide information further defined precise relationships between subcortical white matter structures and cerebral neoplasms. Witwer et al. (37) classified the white matter tracts involved by tumors into 4 types: displaced, edematous, infiltrated, and disrupted according to the spatial relationship between myelinated fiber tracts and tumors represented in diffusion tensor images. Similarly, in our patient sample, white matter tracts alteration were characterized as follows: displaced if the fiber tracts maintained normal anatomic structure but were situated in an abnormal location or with an abnormal orientation; infiltrated if they showed partial disintegration of fiber bundles and sparse relative to the corresponding tract in the contralateral hemisphere; disrupted if the continuity of fiber tracts were interrupted. However, as for individual patient, there usually more than one of these three radiological alterations coexistent. With the aid of DTI in each case, the surgical planning for tumor excision were designed according to anatomical information about white matter tract location, orientation, and projections, radical or subtotal resection were achieved in the majority cases of this group, with no postoperative loss of the neurological function.
Recently, some clinical trials $(15,24)$ reported that fiber tract data was integrated into a standard neuronavigation system, allowing for intraoperative visualization and localization of major white matter tracts such as the pyramidal tract or optic radiation. The results showed that the knowledge of the position of major white matter tracts during surgery may help to prevent too extensive resections, which could potentially damage major white matter tracts and result in postoperative neurological deficits. However, as a new fiber tracts imaging technique, DTI still need to overcome limitations such as the accurate placement of seed regions, image distortions, fiber crossings. Further progress will also relate to a more accurate reconstruction of neural connectivity patterns (25).

\section{CONCLUSION}

In this study, multimodal magnetic resonance imaging techniques were used in preoperative radiological evaluation for patients with brain gliomas. MRS allowed the precise preoperative diagnosis and assessment of pathologic degrees of the tumor. BOLD and DTI allowed detection of functional cortical areas as well as subcortical connectivity, which were important in surgical planning and in predicting the extent of safe resection in patients with gliomas involving the eloquent 
areas. Therefore, a combination of these various techniques is able to provide tailored surgical treatment according to individual radiological information to optimize the benefit/ risk ratio of the surgery, decreasing the rate of permanent deficit and even improving the quality of life of patients.

\section{REFERENCES}

1. Barba I, Moreno A, Martinez-Pérez I, Tate AR, Cabañas ME, Baquero M, Capdevila A, Arús C: Magnetic resonance spectroscopy of brain hemangiopericytomas: High myoinositol concentrations and discrimination from meningiomas. J Neurosurg 94(1):55-60, 2001

2. Benson RR, FitzGerald DB, LeSueur LL, Kennedy DN, Kwong KK, Buchbinder BR, Davis TL, Weisskoff RM, Talavage TM, Logan WJ, Cosgrove GR, Belliveau JW, Rosen BR: Language dominance determined by whole brain functional MRI in patients with brain lesions. Neurology 52(4):798-809, 1999

3. Bonavita S, Di Salle F, Tedeschi G: Proton MRS in neurological disorders. Eur J Radiol 30(2):125-131, 1999

4. Buhl R, Nabavi A, Wolff S, Hugo HH, Alfke K, Jansen O, Mehdorn HM: MR spectroscopy in patients with intracranial meningiomas. Neurol Res 29(1):43-46, 2007

5. Chen J, Huang SL, Li T, Chen XL: In vivo research in astrocytoma cell proliferation with $1 \mathrm{H}$-magnetic resonance spectroscopy: Correlation with histopathology and immunohistochemistry. Neuroradiology 48(5):312-318, 2006

6. Chernov MF, Nakaya K, Kasuya H, Kato K, Ono $Y$, Yoshida S, Nakamura R, Suzuki T, Muragaki Y, Iseki H, Kubo O, Hori T, Takakura K: Metabolic alterations in the peritumoral brain in cases of meningiomas: 1H-MRS study. J Neurol Sci 284(12):168-174, 2009

7. Ferraz-Filho JR, Santana-Netto PV, Rocha-Filho JA, Sgnolf A, Mauad F, Sanches RA: Application of magnetic resonance spectroscopy in the differentiation of high-grade brain neoplasm and inflammatory brain lesions. Arq Neuropsiquiatr 67(2A):250-253, 2009

8. Gajewicz W, Papierz W, Szymczak W, Goraj B: The use of proton MRS in the differential diagnosis of brain tumors and tumor-like processes. Med Sci Monit 9(9):MT97-105, 2003

9. Gumprecht $\mathrm{H}$, Ebel GK, Auer DP, Lumenta CB: Neuronavigation and functional MRI for surgery in patients with lesion in eloquent brain areas. Minim Invasive Neurosurg 45(3): 151-153, 2002

10. Håberg A, Kvistad KA, Unsgård G, Haraldseth O: Preoperative blood oxygen level-dependent functional magnetic resonance imaging in patients with primary brain tumors: Clinical application and outcome. Neurosurgery 54(4): 902-914, 2004

11. Howe FA, Barton SJ, Cudlip SA, Stubbs $M$, Saunders DE, Murphy M, Wilkins P, Opstad KS, Doyle VL, McLean MA, Bell BA, Griffiths JR: Metabolic profiles of human brain tumors using quantitative in vivo $1 \mathrm{H}$ magnetic resonance spectroscopy. Magn Reson Med 49(2):223-232, 2003

12. Izumiyama H, Abe T, Tanioka D, Fukuda A, Kunii N: Clinicopathological examination of glioma by proton magnetic resonance spectroscopy background. Brain Tumor Pathol 21(1):39-46, 2004
13. Jenkinson MD, Smith TS, Joyce K, Fildes D, du Plessis DG, Warnke PC, Walker C: MRS of oligodendroglial tumors: Correlation with histopathology and genetic subtypes. Neurology 64(12):2085-2089, 2005

14. Jeun SS, Kim MC, Kim BS, Lee JM, Chung ST, Oh CH, Lee SY, Choe BY: Assessment of malignancy in gliomas by 3T 1H MR spectroscopy. Clin Imaging 29(1):10-15, 2005

15. Kamada K, Todo T, Masutani Y, Aoki S, Ino K, Takano T, Kirino T, Kawahara N, Morita A: Combined use of tractographyintegrated functional neuronavigation and direct fiber stimulation. J Neurosurg 102(4):664-672, 2005

16. Kang TW, Kim ST, Byun HS, Jeon P, Kim K, Kim H, Lee Jl: Morphological and functional MRI, MRS, perfusion and diffusion changes after radiosurgery of brain metastasis. Eur J Radiol 72(3):370-380, 2009

17. Lai PH, Ho JT, Chen WL, Hsu SS, Wang JS, Pan HB, Yang CF: Brain abscess and necrotic brain tumor: Discrimination with proton MR spectroscopy and diffusion-weighted imaging. AJNR Am J Neuroradiol 23(8):1369-1377, 2002

18. Lai PH, Hsu SS, Ding SW, Ko CW, Fu JH, Weng MJ, Yeh LR, Wu MT, Liang HL, Chen CK, Pan HB: Proton magnetic resonance spectroscopy and diffusion-weighted imaging in intracranial cystic mass lesions. Surg Neurol 68 Suppl 1:S25-36, 2007

19. Magalhaes A, Godfrey W, Shen Y, Hu J, Smith W: Proton magnetic resonance spectroscopy of brain tumors correlated with pathology. Acad Radiol 12(1):51-57, 2005

20. Majós C, Alonso J, Aguilera C, Serrallonga M, Pérez-Martín J, Acebes JJ, Arús C, Gili J: Proton magnetic resonance spectroscopy ((1)H MRS) of human brain tumours: Assessment of differences between tumour types and its applicability in brain tumour categorization. Eur Radiol 13(3):582-591, 2003

21. Mikulis DJ, Roberts TP: Neuro MR: Protocols. J Magn Reson Imaging 26(4):838-847, 2007

22. Murphy PS, Rowland IJ, Viviers L, Brada M, Leach MO, DzikJurasz AS: Could assessment of glioma methylene lipid resonance by in vivo (1)H-MRS be of clinical value? $\mathrm{Br} J$ Radiol 76(907):459-463, 2003

23. Nelson SJ: Multivoxel magnetic resonance spectroscopy of brain tumors. Mol Cancer Ther 2(5):497-507, 2003

24. Nimsky C, Ganslandt O, Fahlbusch R: Implementation of fiber tract navigation. Neurosurgery 61(1 Suppl):306-317, 2007

25. Nimsky C, Ganslandt O, Hastreiter P, Wang R, Benner T, Sorensen AG, Fahlbusch R: Preoperative and intraoperative diffusion tensor imaging-based fiber tracking in glioma surgery. Neurosurgery 61(1 Suppl):178-185, 2007

26. Olausson H, Ha B, Duncan GH, Morin C, Ptito A, Ptito M, Marchand S, Bushnell MC: Cortical activation by tactile and painful stimuli in hemispherectomized patients. Brain 124:916-927, 2001

27. Opstad KS, Bell BA, Griffiths JR, Howe FA: An investigation of human brain tumour lipids by high-resolution magic angle spinning $1 \mathrm{H}$ MRS and histological analysis. NMR Biomed 21(7):677-685, 2008 
28. Opstad KS, Murphy MM, Wilkins PR, Bell BA, Griffiths JR, Howe FA: Differentiation of metastases from high-grade gliomas using short echo time $1 \mathrm{H}$ spectroscopy. J Magn Reson Imaging 20(2):187-192, 2004

29. Roberts TP, Ferrari P, Perry D, Rowley HA, Berger MS: Presurgical mapping with magnetic source imaging: Comparisons with intraoperative findings. Brain Tumor Pathol 17(2):57-64, 2000

30. Rutten GJ, Ramsey N, Noordmans HJ, Willems P, van Rijen $P$, Berkelbach van der Sprenkel JW, Viergever $M$, van Veelen C: Toward functional neuronavigation: Implementation of functional magnetic resonance imaging data in a surgical guidance system for intraoperative identification of motor and language cortices. Technical note and illustrative case. Neurosurg Focus 15(1):E6, 2003

31. Saunders DE: MR spectroscopy in stroke. Br Med Bull 56(2):334-345, 2000

32. Schlösser R, Hunsche $S$, Gawehn J, Grunert P, Vucurevic G, Gesierich T, Kaufmann B, Rossbach W, Stoeter P: Characterization of BOLD-fMRI signal during a verbal fluency paradigm in patients with intracerebral tumors affecting the frontal lobe. Magn Reson Imaging 20(1):7-16, 2002
33. Schulder M, Maldjian JA, Liu WC, Holodny Al, Kalnin AT, Mun IK, Carmel PW: Functional image-guided surgery of intracranial tumors located in or near the sensorimotor cortex. J Neurosurg 89(3):412-418, 1998

34. Senft C, Hattingen E, Pilatus U, Franz K, Schanzer A, Lanfermann H, Seifert V, Gasser T: Diagnostic value of proton magnetic resonance spectroscopy in the noninvasive grading of solid gliomas: Comparison of maximum and mean choline values. Neurosurgery 65(5):908-913, 2009

35. Sunaert S: Presurgical planning for tumor resectioning. J Magn Reson Imaging 23(6):887-905, 2006

36. Weber MA, Giesel FL, Stieltjes B: MRI for identification of progression in brain tumors: From morphology to function. Expert Rev Neurother 8(10):1507-1525, 2008

37. Witwer BP, Moftakhar R, Hasan KM, Deshmukh P, Haughton V, Field A, Arfanakis K, Noyes J, Moritz CH, Meyerand ME, Rowley $\mathrm{HA}$, Alexander AL, Badie B: Diffusion-tensor imaging of white matter tracts in patients with cerebral neoplasm. J Neurosurg 97(3):568-575, 2002

38. Yang I, Aghi MK: New advances that enable identification of glioblastoma recurrence. Nat Rev Clin Oncol 6(11): 648-657, 2009 